\title{
DIFFERENCE IN PERCEPTION OF URBAN GREEN SPACES BETWEEN DANCHI AND APARTMENT RESIDENTS IN TOKIWADAIRA, MATSUDO CITY, JAPAN (Perbedaan dalam Persepsi Ruang Hijau Perkotaan di antara Penghuni Kompleks Rumah Susun dan Apartemen di Tokiwadaira, Kota Matsudo, Jepang)
}

\author{
Prita Indah Pratiwi ${ }^{1}$, Minseo Kim ${ }^{1}$, and Katsunori Furuya ${ }^{1}$ \\ Landscape Architecture Program, Graduate School of Horticulture, Chiba University, \\ 648 Matsudo Matsudo-shi Chiba 271-8510 Japan.
}

*Penulis korespondensi. Tel: 081382426570. Email: pritaindahpratiwi@ymail.com.

\author{
Diterima: 18 Mei 2018
}

Disetujui: 5 Oktober 2018

\begin{abstract}
In Japan, where most of the population now comprises elderly people, various social problems have emerged, including lack of workers, inadequate care for elderly people, lower birthrate, the abandonment of local areas, and lack of community. In highly populated urban areas, city planners propose sustainable landscape planning but sometimes ignore the public, eliminating their sense of place. This study aimed to clarify the differences in green space perception between residents of danchi and apartments in Tokiwadaira, Matsudo, to learn what residents' attributes may influence their perceptions, and to formulate factors of recognition and awareness of urban green spaces. The research was conducted in three stages: a recognition and awareness survey, analysis, and interpretation. A Mann-Whitney U test and Welch's $t$ test were applied to examine significant differences in perception level; a Chi-square test was applied to examine the relationship between residents' attributes and volunteering activity; finally, factor analysis was applied to characterize residents' recognition and awareness of nature and green spaces. The results demonstrated three significant differences regarding the benefits of green spaces between danchi and apartment residents, and five significant differences in their interest in green spaces. The attributes influencing danchi residents' perceptions were gender and age, while those influencing apartment residents were age, existence of children, employment status, length of stay, and existence of green spaces. The three factors accounting for residents' interest in green spaces and nature were: high recognition and awareness, moderate recognition and awareness, and low recognition and awareness. The results may prove useful as guidance for specific local governments in relation to urban green space planning and design.
\end{abstract}

Kata kunci: recognition, awareness, landscape perception, public participation, urban green space.

\begin{abstract}
Abstrak
Di Jepang di mana sebagian besar penduduknya terdiri atas orang lanjut usia, berbagai masalah sosial telah terjadi, seperti kurangnya tenaga kerja, perawatan bagi orang lanjut usia yang rendah, kelahiran anak-anak yang rendah, terabaikannya daerah setempat, dan kurangnya komunitas. Di daerah perkotaan yang berpenduduk padat, perencana kota mengusulkan perencanaan lanskap berkelanjutan, tetapi terkadang mengabaikan publik dan menghilangkan makna tempat mereka. Penelitian ini bertujuan untuk memperjelas perbedaan persepsi ruang hijau antara penghuni di kompleks rumah susun semi publik dan apartemen di Tokiwadaira, Matsudo, untuk mengetahui atribut penghuni yang dapat mempengaruhi persepsi mereka, dan untuk merumuskan faktor-faktor pengenalan dan kesadaran akan ruang hijau perkotaan. Penelitian ini dilakukan dalam tiga tahap: survei kesadaran dan pengenalan, analisis, dan interpretasi. Uji Mann-Whitney $U$ dan Welch's t digunakan untuk menguji perbedaan level persepsi yang signifikan antara penghuni danchi dan apartemen. Uji Chi-square digunakan untuk menguji hubungan antara atribut penghuni dan kegiatan sukarela, terakhir analisis faktor digunakan untuk mengkarakterisasi pengenalan dan kesadaran penghuni terhadap alam dan ruang hijau. Hasil penelitian menunjukkan bahwa terdapat tiga perbedaan signifikan mengenai manfaat ruang hijau di antara penghuni danchi dan apartemen, dan lima perbedaan signifikan terhadap minat ruang hijau. Atribut yang mempengaruhi persepsi penduduk danchi adalah gender dan usia, sedangkan hal-hal yang mempengaruhi penghuni apartemen adalah usia, keberadaan anak, status pekerjaan, lama tinggal, dan keberadaan ruang hijau. Tiga faktor yang menentukan minat penghuni terhadap alam dan ruang hijau di antaranya: pengenalan dan kesadaran yang tinggi, pengenalan dan kesadaran yang sedang, serta pengenalan dan kesadaran yang rendah. Hasil penelitian ini dapat berguna sebagai panduan perencanaan dan desain ruang hijau kota untuk pemerintah lokal.
\end{abstract}

Keywords: pengenalan, kepedulian, persepsi lanskap, partisipasi publik, ruang hijau perkotaan. 


\section{INTRODUCTION}

Urban areas are becoming increasingly populated and Japan is one of the most highly urbanized countries in the world. During the eighteenth century, Tokyo was the largest city in the world, with an estimated 1 million inhabitants. Today, Tokyo Metropolitan Area, as opposed to the city of Tokyo, is the largest in the world with approximately 39 million people. In Japan, the majority of the population comprises elderly people, leading to a lack of workers, inadequate care for elderly people, lower birthrate, abandonment of local areas, and lack of community.

Ronald and Alexy (2011) explained that the new pillars of housing policy introduced in the $1950 \mathrm{~s}$ began to redirect resources toward modernizing the housing system. These included, firstly, the Government Housing Loan Corporation Act, which provided government funding for longterm, low interest mortgages; secondly, the Public Housing Act, which provided a limited amount of subsidies to the public housing private market; and third, the Japan Housing Corporation Act, which developed multi-family housing estates for middle income households in large cities. A notable innovation was the JHC's construction of danchi complexes from the mid-1950s. Danchi are multifamily housing estates comprising concrete apartment structures. Their construction aimed to develop suburban neighborhoods and promote modern family lifestyles orientated around compact apartment units. Buildings were initially 5-12 stories high and surrounded by parking areas and playgrounds.

The first high-rise construction became possible after the 1965 restrictions on building heights to $31 \mathrm{~m}$. However, high-rise building initially proved problematic in terms of construction, adapting the existing infrastructure, as well as the impact on neighboring communities. Increasingly, smaller scale private sector apartments, or manshon, were constructed for rent in and around urban areas. Manshon properties were not only cheaper but often better connected to the city than many new housing developments, and over time designs were diversified to suit single and larger households, as well as wealthier consumers (Ronald and Alexy, 2011).

Several major tasks include realigning the urban structure, especially supplying housing in good residential districts, and improving the infrastructure. To this end, Japan must tackle the urgent problem of residential development. Explorations are now under way to institute a more community-led mode of urban planning in which local residents can participate. Cities need to be more innovative and take advantage of local strengths. Second, urban redevelopment needs to place more emphasis on cultural perspectives, emphasizing the distinctive local or regional personality. Third, Japanese cities must prepare for the coming "gray society." Some housing projects for the elderly are going up in Tokyo and other cities, but urban development must be adapted to the needs of elderly people, by, for example, constructing more parks and replacing steps with slopes (Karan, 2004).

Tokiwadaira town is located in the north-east of Tokyo where the concrete flats of the oldest semipublic housing were built in the early 1960s. Its demographics are changing rapidly. The latest data show that the total population in Tokiwadaira town in 2017 was 28,875 people, comprising 14,932 households (males: 14,231; females: 14,644). In total, $38.29 \%$ of the total population $(11,056$ people $)$ live in Tokiwadaira housing complex, most of whom are over $65 \mathrm{~s}(47.5 \%$ $(3,559)$ in 2017 and $45.6 \%(3,512)$ in 2016) who moved there upon retirement and now live alone. There are also private apartments surrounding Tokiwadaira housing complex, which were built in the 1970s-1980s. We assume that people in different types of dwelling and neighborhood might have different perceptions based on their dwelling situation, record of volunteering activity, and personal factors. By investigating landscape perception, the variation in resident types could be understood to describe green space quality. Due to the differences in perception of nature and urban green spaces, it is necessary to clarify the differences in green space perception between the residents of Tokiwadaira housing complex and the private apartments surrounding it, to learn what residents' attributes may influence their perceptions, and to formulate factors inducing residents' awareness and recognition of urban green spaces.

\section{METHODS}

The participatory planning and design method plays a key role in ensuring user satisfaction (Turan et al., 2016). It helps formulate comfortable, legible, and convenient green spaces with a variety of activities to meet public needs. With participatory planning, residents are actively involved in urban green space planning and the design process; this results in a greater public spirit, social connection, user satisfaction, significant financial saving, and a better maintained environment. 


\section{Study area}

The object of research comprised residents' perceptions of nature and green spaces. To assess their recognition and awareness of nature and green space, residents of different types of dwelling, danchi public housing and apartments in Tokiwadaira town, were selected as respondents (Figure 1). The survey was conducted from January to February 2018.

\section{Data collection and sampling}

Nowadays, the context of landscape perception, particularly for assessing recognition and awareness of nature and green spaces, involves not only experts and students (Ueda, 2006; Pratiwi et al., 2014 ), but also general society and local residents (Ross \& Wall, 1999; Ueda, 2009). Stratified random sampling was used in this research. The respondents comprised residents living in apartments and danchi. The data were obtained through a survey questionnaire administered to 2020 residents; the number of returned questionnaires comprised 93 from danchi respondents and 127 from apartment respondents. The questionnaire was arranged using their native language and filled out using pen to avoid systematic errors.

The sample size was sufficient as the research sample for each type of dwelling exceeded 30 respondents (Roscoe, 1975; Fraenkel \& Wallen, 1993). The data were obtained from questionnaire surveys using the posting method with a return envelope.

\section{Data analysis procedure}

Based on Lucas (1991) and Pratiwi et al, $\left(2014^{\mathrm{b}}\right)$, the research procedure for developing a design concept consisted of a recognition and awareness survey, recognition and awareness analysis, and interpretation.

\section{Recognition and Awareness Survey}

1. Living space and volunteering activity

The residents were asked to describe the character of their living space and their activities in the green spaces, including their activity intensity in green spaces, gardening, volunteering activity, expected number of hours participating in volunteering activity, etc. Residents then chose their perceived level of benefit, constraint in relation to, and interest in nature and green spaces using a 5-point Likert Scale from "Extremely,"
"Sometimes," "Neither," "Not so much," and "Not at all," as described in Kim et al. (2017).

2. Residents' attributes

It was necessary to clarify residents' attributes such as gender, age, existence of children, employment status, and length of stay. As Pratiwi et al. (2014a) suggested, these factors may lead to differences in perception and preference.

\section{Recognition and awareness analysis}

1. Analysis of perception level between danchi and apartment residents

The purpose of this analysis was to examine the significant differences in perceived benefit, constraint, and interest in nature and green spaces. The respective question types consisted of 8,8 , and 10 variables, respectively. A Mann-Whitney $U$ test was applied to examine significant differences in perception level. A Welch's t test was applied to determine the difference in means between the perceptions of danchi and apartment residents.

2. Analysis of attributes influencing perception

The purpose of this analysis was to examine the relationship among residents' attributes and residents' gardening and volunteering activity in green spaces. The questionnaire comprised five variables: gender, age, existence of children, occupation, and length of stay. A Chi-square test was applied to examine these relationships.

3. Factor analysis in perceiving green spaces and nature

The data, consisting of 26 variables of green space perception, were analyzed using factor analysis. Factor analysis using the principal component method and Varimax rotation was applied to characterize residents' recognition and awareness of nature and green spaces. Factor analysis was conducted as follows (Hidayat and Istiadah, 2011): (1) defining variable, (2) counting matrix correlation among variables, (3) extracting factor, and (4) rotating factor.

\section{Interpretation}

Interpretation of recognition and awareness of nature and green space was formulated and derived from analysis of perception level and factor analysis. The differences in residents' recognition and awareness of their surrounding nature and green spaces were considered, to provide guidance on urban green space planning for specific local governments. 


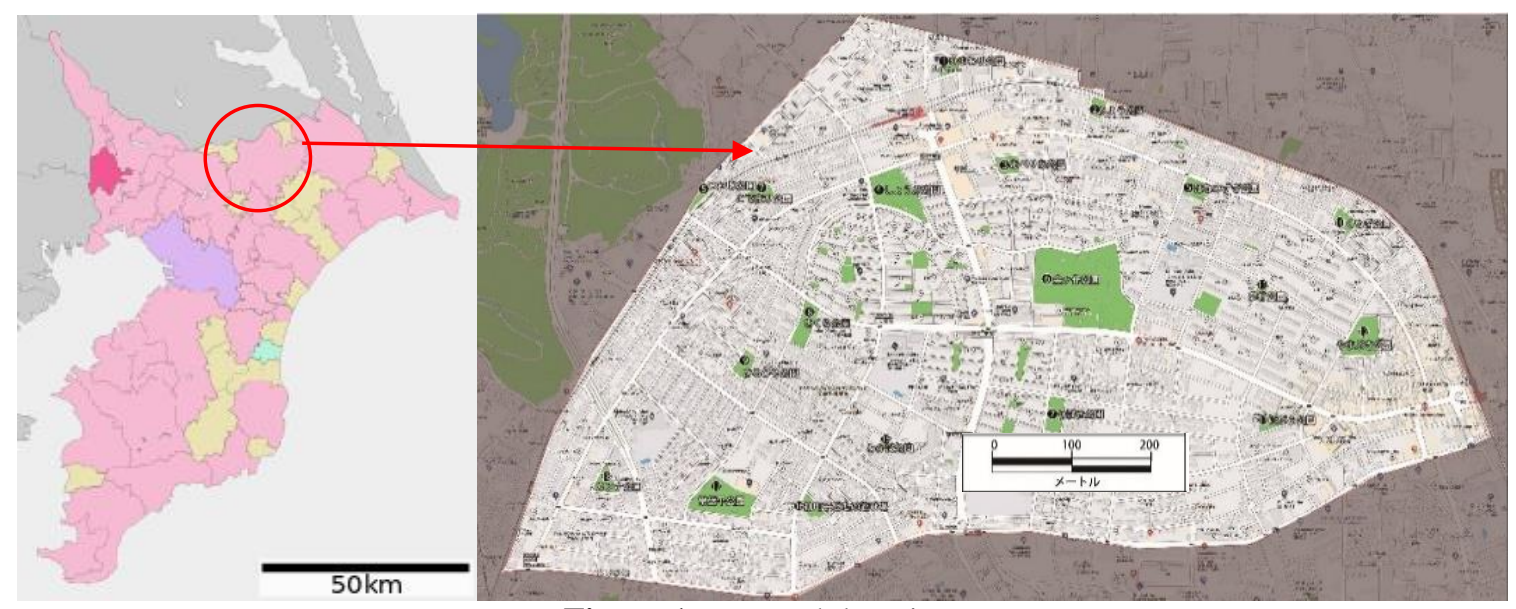

Figure 1. Research location.

Table 1. Benefit of UGS between danchi and apartment residents.

\begin{tabular}{lrrrrrrrr}
\hline & $\begin{array}{r}\text { Beautiful } \\
\text { urban } \\
\text { landscape }\end{array}$ & $\begin{array}{r}\text { Feel the } \\
\text { nature }\end{array}$ & Near & $\begin{array}{r}\text { Free } \\
\text { activity }\end{array}$ & $\begin{array}{r}\text { Children } \\
\text { can play }\end{array}$ & $\begin{array}{r}\text { Easily } \\
\text { inhabit } \\
\text { life }\end{array}$ & $\begin{array}{r}\text { Control } \\
\text { dust }\end{array}$ & $\begin{array}{r}\text { Air } \\
\text { conditioning }\end{array}$ \\
\hline $\begin{array}{l}\text { Mann } \\
\begin{array}{l}\text { Whitney } \\
\text { U test }\end{array}\end{array}$ & 0.829 & 0.738 & $0.037^{* *}$ & 0.363 & 0.168 & 0.488 & $0.003^{* * *}$ & 0.900 \\
$\begin{array}{l}\text { Welch's } \\
\mathrm{t} \text { test }\end{array}$ & 0.254 & 0.382 & 0.143 & 0.570 & $0.089^{*}$ & 0.804 & $0.008^{* * *}$ & 0.812 \\
\hline
\end{tabular}

Note: $\mathrm{p}^{*}<0.1, \mathrm{p}^{* *<0}<05, * * * \mathrm{p}<0.01$

\section{RESULTS AND DISCUSSION}

\section{Difference in perception level}

Generally, the trends of danchi and apartment residents were similar, from the highest to lowest perception level respectively: "extremely," "sometimes," "neither," "not so much," and "not at all." The Mann Whitney U test demonstrated a significant difference in perceptions of the benefit of green spaces between danchi and apartment residents, especially in the "it is near" $(\mathrm{p}=0.069)$ and "it can control the dust" variables $(\mathrm{p}=0.003)$. Forty-six percent of Danchi residents but only $41 \%$ of apartment residents perceived that green spaces could control the dust. Welch's t-test was applied to determine whether the means of danchi and apartment residents' perceptions were equal. The result was quite different from the Mann Whitney $\mathrm{U}$ test in that a significant difference in the perceived benefit of green spaces was only found in "It is a place where children can play" $(p=0.089)$, with apartment residents having a higher mean than danchi residents ( 4.53 vs. 4.34$)$, and "it can control the dust" $(\mathrm{p}=0.0008)$, where danchi residents had a higher mean (4.22 vs 3.86).

Fifty-one percent of apartment residents but only $26 \%$ of danchi residents reported "sometimes" thinking about how near the green space is to their house. Tokiwadaira danchi was surrounded by several types of green space, including neighborhood parks, playgrounds, small front gardens, backyards, greenways, and pine forests.
There are more than 20 species of tree in Tokiwadaira danchi with tree canopies providing environmental benefits such as removing air pollution. Moreover, as Sulistyantara and Pratiwi, (2011a) described, the 325.38 hectares (57\%) of green space in the tourism area provide economic benefit to the tune of $\$ 172.029$.

Neither the Mann Whitney $U$ test nor the Welch's $t$ test showed a significant difference between danchi and apartment residents in perceived constraints to accessing green spaces. Most danchi and apartment residents thought little about the constraints of green spaces. The highest percentage of danchi residents reported thinking "not so much" about whether "the plants are wellmanaged" and "it is hard to enter" (34\%), while apartment residents thought "not so much" about "it is hard to enter" $(55 \%)$.

The danchi and apartment residents differed in terms of their interest in nature and green spaces as shown by both the Mann Whitney $U$ test and Welch's t test: "I cherish nature in cities such as animals and plants" ( $p=0.069)$; "I know common plants, animals, and insects in the area" $(\mathrm{p}=0.000)$; "I feel affection for the region through plants, animals, and insects in the area" $(\mathrm{p}=0.001)$; "it is a well-managed place" ( $\mathrm{p}=0.001 ; 0.004)$; and "it is a convenient place to use" $(\mathrm{p}=0.003 ; 0.007)$. Danchi residents differed from apartment residents in terms of their interest in nature and green spaces, as shown in the graph of means below $(3.39,3.88$, $3.80,3.88$ vs $2.83,3.46,3.39,3.51$ ). 


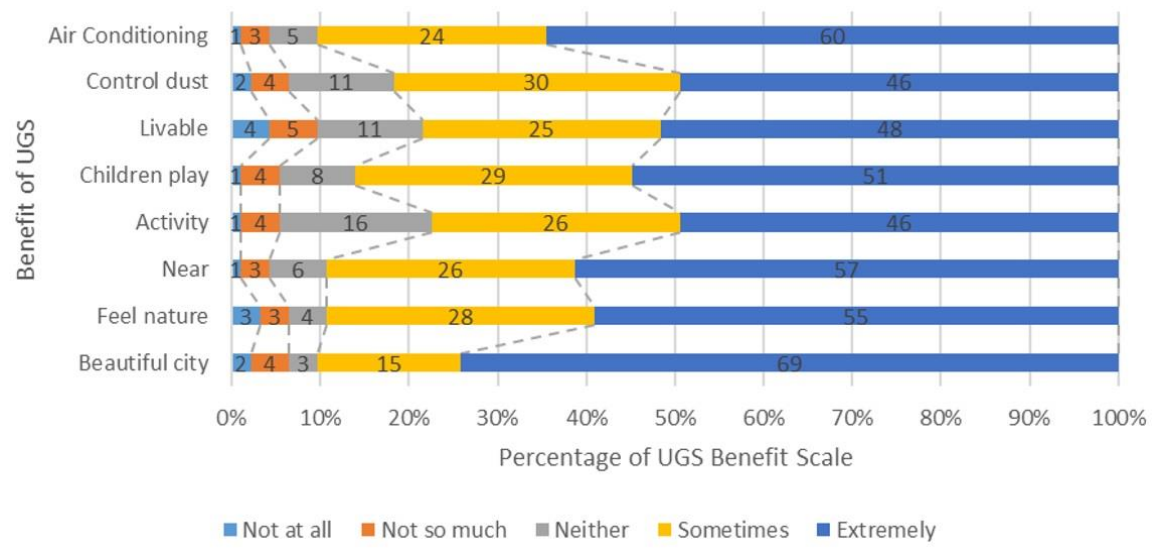

(a)

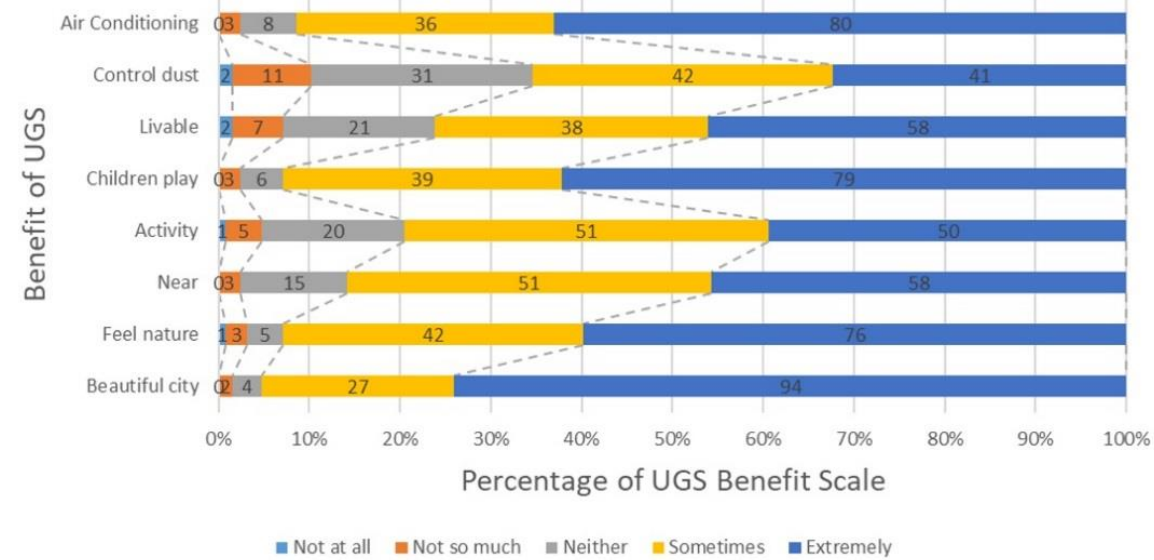

(b)

Figure 2. Perception level of benefit of UGS among (a) Danchi residents and (b) apartmen residents.

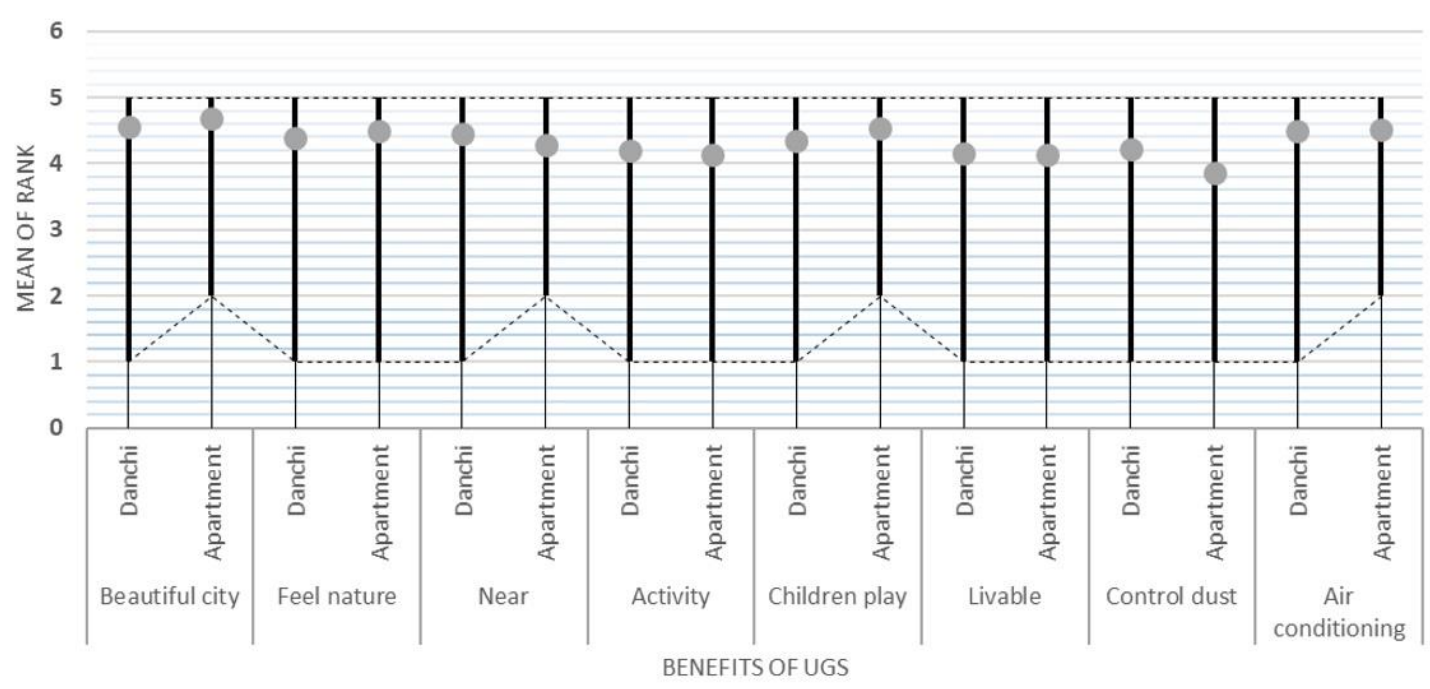

Figure 3. Mean of benefits of green space variables.

Table 2. Constraints of UGS between danchi and apartment residents.

\begin{tabular}{lcccccccc}
\hline & $\begin{array}{c}\text { Owner } \\
\text { conflict }\end{array}$ & $\begin{array}{c}\text { Risk of } \\
\text { injury }\end{array}$ & $\begin{array}{c}\text { Hard to } \\
\text { enter }\end{array}$ & $\begin{array}{c}\text { A lot of } \\
\text { garbage }\end{array}$ & $\begin{array}{c}\text { Contaminated } \\
\text { place }\end{array}$ & $\begin{array}{c}\text { Not well } \\
\text { maintained }\end{array}$ & $\begin{array}{c}\text { Narrow } \\
\text { Highly } \\
\text { likely to be } \\
\text { lost }\end{array}$ \\
\hline $\begin{array}{l}\text { Mann } \\
\begin{array}{l}\text { Whitney U } \\
\text { test }\end{array}\end{array}$ & 0.143 & 0.281 & 0.643 & 0.236 & 0.584 & 0.996 & 0.558 & 0.653 \\
$\begin{array}{l}\text { Welch's t test } \\
\text { Melch }\end{array}$ & 0.209 & 0.345 & 0.705 & 0.154 & 0.535 & 0.937 & 0.605 & 0.816 \\
\hline
\end{tabular}

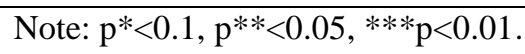




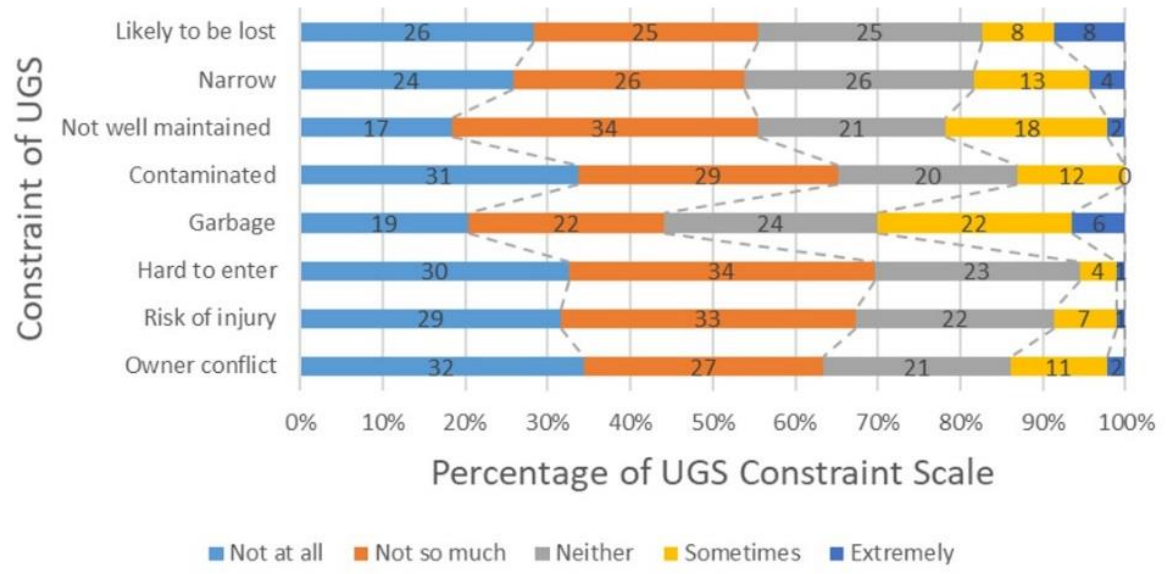

(a)

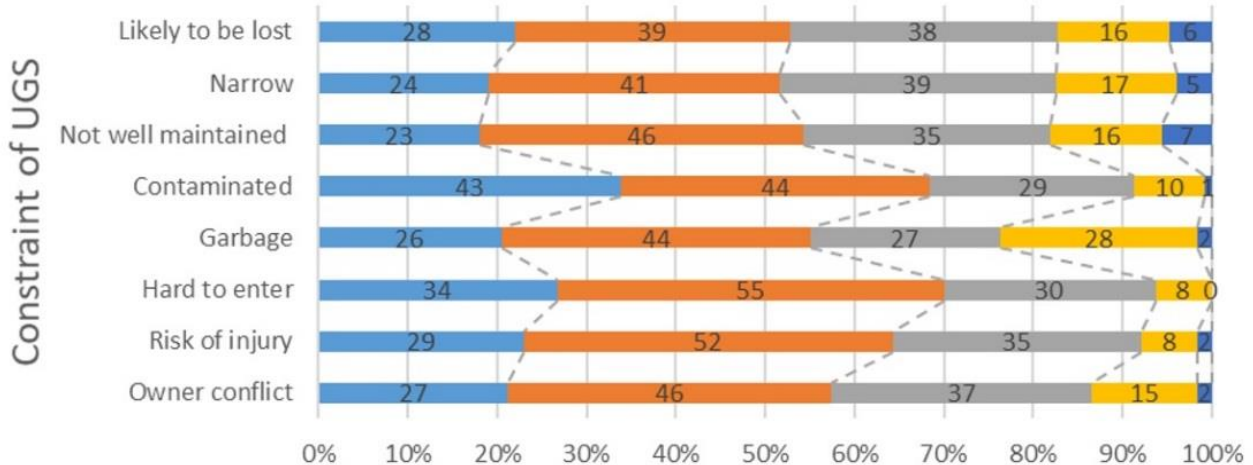

Percentage of UGS Constraint Scale

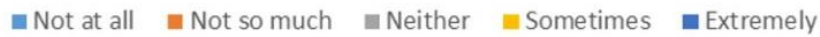

(b)

Figure 4. Perception level of constraints of UGS among (a) Danchi residents and (b) apartmen residents

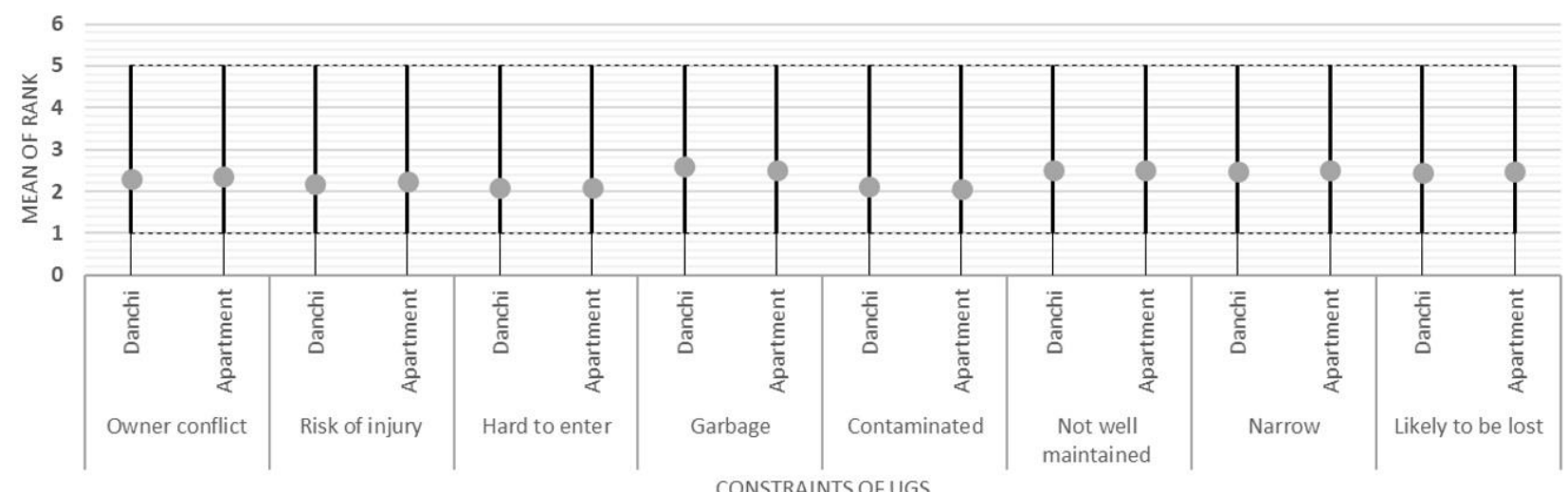

Figure 5. Mean of constraints of green space variables

In total, $12 \%$ of Danchi residents knew the names of common creatures, $28 \%$ felt affection, $29 \%$ perceived it is a well-managed place, and $32 \%$ perceived it as convenient for use, while the corresponding figures for apartment residents were $5,18,15$, and $20 \%$ respectively. Danchi residents had more positive awareness and recognition of nature and green spaces than apartment residents. The variation of green space forms near
Tokiwadaira danchi positively affected their knowledge, feelings, and behavior. However, this was not sufficient to create life satisfaction. The growing elderly population is a major concern in Tokiwadaira town, not only financially, but also socially. Contact with nature has many therapeutic benefits, and it is crucial to create community spaces by understanding local residents' characters (Othman and Fadzil, 2014). 
Table 3. Interest in UGS of danchi and apartment residents using Mann Whitney U Test.

\begin{tabular}{lcccccccccc}
\hline & $\begin{array}{c}\text { Cherish } \\
\text { nature }\end{array}$ & $\begin{array}{c}\text { Cheers } \\
\text { up life }\end{array}$ & $\begin{array}{c}\text { Environment } \\
\text { coexist }\end{array}$ & $\begin{array}{c}\text { Willing } \\
\text { to } \\
\text { volunteer }\end{array}$ & $\begin{array}{c}\text { Time } \\
\text { for } \\
\text { nature }\end{array}$ & $\begin{array}{c}\text { Money } \\
\text { for } \\
\text { nature }\end{array}$ & $\begin{array}{c}\text { Know } \\
\text { the } \\
\text { creatures }\end{array}$ & $\begin{array}{c}\text { Affection } \\
\text { for nature }\end{array}$ & $\begin{array}{c}\text { Well } \\
\text { managed } \\
\text { place }\end{array}$ & $\begin{array}{c}\text { Convenient } \\
\text { place }\end{array}$ \\
\hline $\begin{array}{l}\text { Mann } \\
\begin{array}{l}\text { Whitney } \\
\text { U test }\end{array}\end{array}$ & $0.069 *$ & 0.703 & 0.724 & 0.184 & 0.616 & 0.587 & $0.000^{* * *}$ & $0.001^{* * * *}$ & $0.001 * * *$ & $0.003 * * *$ \\
$\begin{array}{l}\text { Welch's } \\
\text { t test }\end{array}$ & 0.134 & 0.947 & 0.815 & 0.193 & 0.529 & 0.647 & $0.000^{* * *}$ & $0.002 * * *$ & $0.004 * * *$ & $0.007 * * *$ \\
\hline
\end{tabular}

Note: $\mathrm{p}^{*<0.1, \mathrm{p}^{* *<0} 0.05, * * * \mathrm{p}<0.01}$

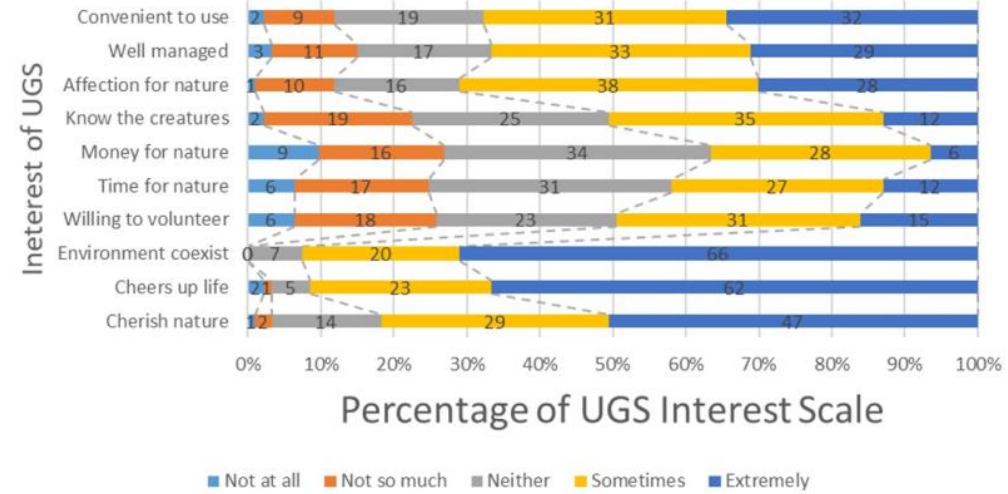

(a)

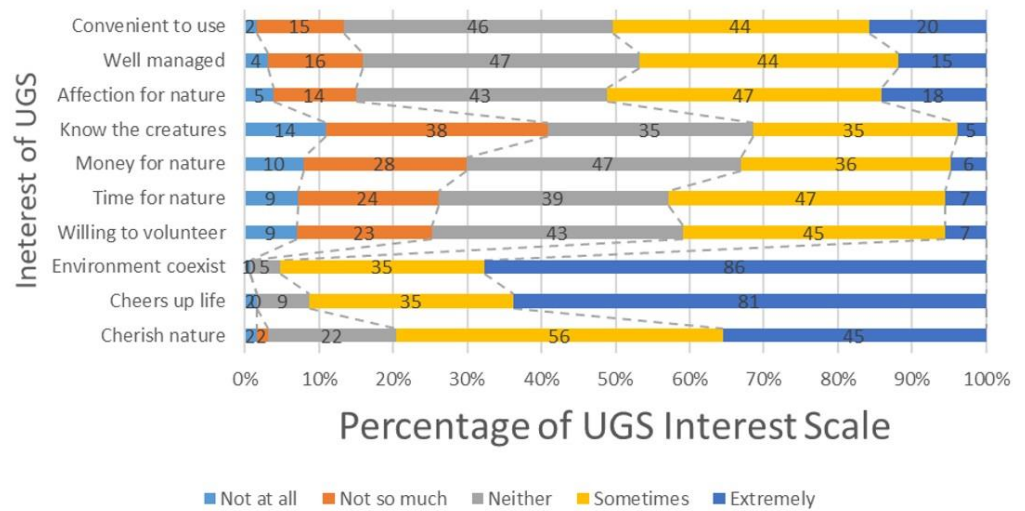

(b)

Figure 6. Perception level of interest of UGS among (a) Danchi residents and (b) apartmen residents

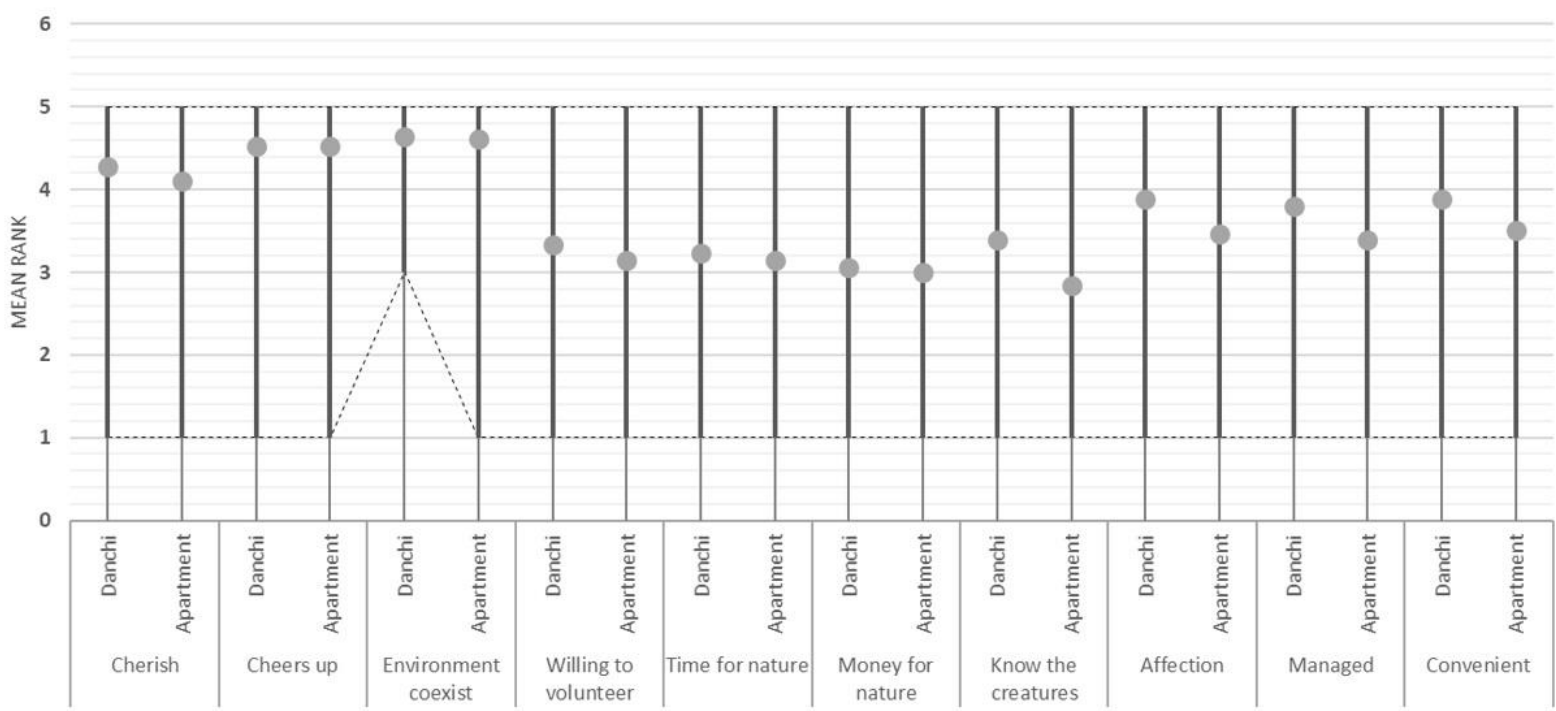

INTEREST OF UGS

Figure 7. Mean interest in nature and green space variables. 


\section{Attributes influencing residents' perceptions}

Only two attributes influenced the perceptions of danchi residents: gender and age. Gardening activity and activity in green spaces were conducted by female residents (31.2 and $21.5 \%$, respectively), while male residents tended not to use green spaces $(17.2 \%)$. After their wives died, their personal space became narrower. Meanwhile, apartment residents were influenced by age, existence of children, employment status, length of stay, and existence of green spaces. The older they were, the lower their participation in volunteering activity $(22.83 \%)$, had no activities (23.62\%), expected hours per day (17.32\%), expected hours per year $(18.11 \%)$, and did not conduct activities in the green space, especially 50- to 59-year-old residents (11.02\%), while 60- to 69-year-old residents tended to conduct gardening activities at home (15.75\%). Residents without children tended not to have time to participate in volunteering every day $(42.52 \%)$. Unemployed residents tended not to have time to volunteer in a year $(25.98 \%)$. Residents of 11-20 and 21-30 years engaged in gardening activity at home (14.17 and $13.39 \%$ respectively). Variations occurred between how long residents and their families, including older generations, had lived in a particular area and how actively they were involved in the surrounding social network. Among apartment residents, the existence of green spaces was related to activity in green spaces. However, residents whose homes had a large green space tended not to use it $(18.11 \%)$ because they spent their days at the office (57.48\%). It might be that personality and nearby living space situations affected their environmental behavior.

\section{Factors in perceiving green spaces and nature}

Only one factor differed in terms of danchi and apartment residents' perceptions of the benefits of green spaces, namely the multifunctional use of urban green spaces including ecological, aesthetic, and social function. Regarding ecological function, landscape plants instead of air conditioning had an energy-saving function in urban areas, and also controlled dust volumes. Regarding aesthetic function, urban green spaces allow citizens to experience beautiful nature in a compact urban landscape. Regarding social function, urban green spaces provide various opportunities for socializing, sharing, and exchanging ideas.

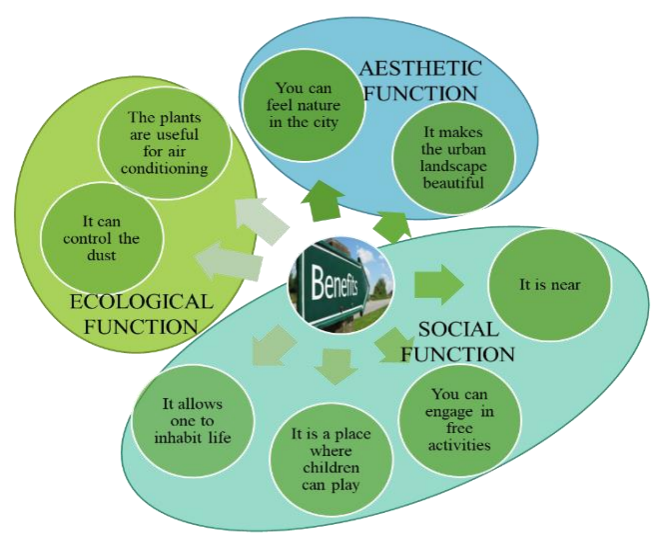

Figure 8. Factors in perceived benefits of green space.

Table 4. Danchi residents' attributes and activities in green spaces

\begin{tabular}{|c|c|c|c|c|c|c|}
\hline $\begin{array}{l}\text { Activity } \\
\text { Respondent } \\
\text { identity }\end{array}$ & $\begin{array}{r}\text { Volunteering } \\
\text { activity }\end{array}$ & $\begin{array}{r}\text { Number of } \\
\text { volunteering } \\
\text { activities }\end{array}$ & $\begin{array}{r}\text { Expected } \\
\text { volunteering } \\
\text { hours per } \\
\text { day }\end{array}$ & $\begin{array}{r}\text { Expected } \\
\text { volunteering } \\
\text { hours per } \\
\text { year }\end{array}$ & $\begin{array}{r}\text { Gardening } \\
\text { activities }\end{array}$ & $\begin{array}{r}\text { Intensity of } \\
\text { activity in } \\
\text { green space }\end{array}$ \\
\hline Gender & 0.419 & 0.695 & 0.493 & 0.470 & $0.023 * *$ & $0.009 * * *$ \\
\hline Age & 0.804 & 1 & 0.887 & 0.083 & 0.795 & 0.225 \\
\hline Existence of children & 0.683 & 0.804 & 0.102 & $0.048 * *$ & 0.152 & 0.516 \\
\hline Employment status & 0.425 & 0.575 & 0.871 & 0.390 & 0.747 & 0.129 \\
\hline Length of stay & 0.228 & 0.357 & 0.883 & 0.880 & 0.384 & 0.149 \\
\hline Existence of a green space & 0.648 & 0.999 & 0.931 & 1 & 0.813 & 0.149 \\
\hline
\end{tabular}

Note: $\mathrm{p}^{*<0.1, \mathrm{p}^{* *<0} 0.05, * * * \mathrm{p}<0.01}$

Table 5. Apartment residents' attributes and activities in green spaces.

\begin{tabular}{lrrrrrr}
\hline Activity & $\begin{array}{r}\text { Volunteering } \\
\text { activity }\end{array}$ & $\begin{array}{r}\text { Number of } \\
\text { volunteerin } \\
\text { g activities }\end{array}$ & $\begin{array}{r}\text { Expected } \\
\text { volunteering } \\
\text { hours per day }\end{array}$ & $\begin{array}{r}\text { Expected } \\
\text { volunteering } \\
\text { hours per year }\end{array}$ & $\begin{array}{r}\text { Gardening } \\
\text { activities }\end{array}$ & $\begin{array}{r}\text { Intensity of } \\
\text { activity in } \\
\text { green spaces }\end{array}$ \\
identity & 1 & 0.550 & 0.365 & 0.409 & 0.884 & 0.565 \\
Gender & $0.036^{* *}$ & $0.0000^{* * *}$ & $0.046^{* *}$ & $0.098^{*}$ & $0.011^{* *}$ & $0.079^{*}$ \\
Age & 0.314 & 0.880 & $0.053^{*}$ & 0.750 & 0.384 & 0.207 \\
Existence of children & 0.968 & 0.363 & 0.211 & $0.059^{*}$ & 0.436 & 0.829 \\
Employment status & 0.591 & 0.231 & 0.319 & 0.323 & $0.056^{*}$ & 0.140 \\
Length of stay & 0.430 & 0.440 & 0.791 & 0.617 & 0.884 & $0.080^{*}$ \\
Existence of a green space & & & & & & \\
\hline
\end{tabular}

Note: $\mathrm{p}^{*<0}<0.1, \mathrm{p}^{* *<}<0.05, * * * \mathrm{p}<0.01$ 
There were two factors related to perceived constraints of green spaces, namely property and security; sanitation, design and maintenance. Regarding property and security, residents tend to visit green spaces with clear ownership, for example public parks that can be accessed freely or theme parks with entrance tickets. Security is an important factor in entering green spaces, such as neighborhood parks with entrance gates, name signs, and an impression of openness. Furthermore, security within green spaces was related to landscape management, overgrown vegetation, or obsolete hard material that could harm the user. Regarding sanitation, design, and maintenance, residents perceived sites with lots of garbage or that might have been contaminated with smoke or pollution to pose a constraint to accessing green spaces. Furthermore, they perceived narrow green spaces and poorly maintained plants as problems that are highly likely to result in the site being lost someday.

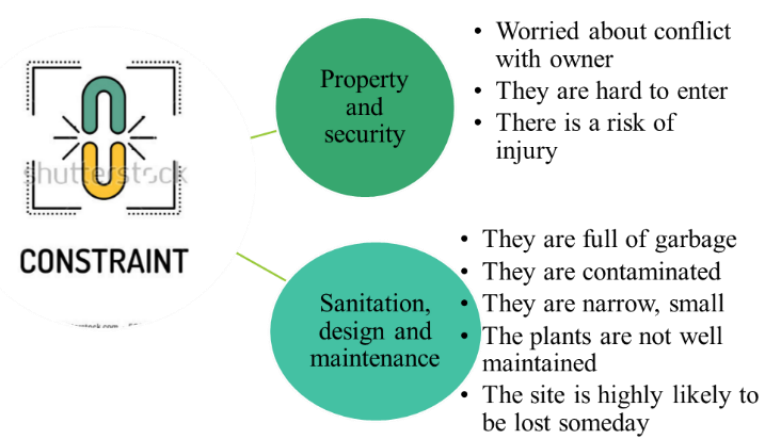

Figure 9. Factors in perceiving constraints of green space.
In general, there were three factors related to interest in green spaces and nature: high recognition and awareness, moderate recognition and awareness, and low recognition and awareness of nature and green spaces. The differences between danchi and apartment residents were that the former tend to spend money on nature in all types of recognition and awareness. Regarding low recognition and awareness, they realized that creatures can coexist with the environment and felt affection for nature, considering nature and green spaces to be convenient and well-managed places. These three different types of interest are vital for constructing community buildings in Tokiwadaira town. Meltzer (2000) explained that a modern sense of community is engendered through: 1) extensive shared visioning and participatory planning leading to the early bonding and socialization of group members, 2) well-defined decision-making based on open, representative, and fair processes - usually consensus, 3) diverse populations with a mix of young and old, owners and renters, families and singles - all sharing a common purpose and providing mutual support, 4) the implementation of landscape design in facilitating informal social contact through well-considered public space planning and public/private zoning, 5) organized shared stewardship of the physical environment through work-groups with high participation, flexibility, balance, and mutual advantage, 6) more sharing of common facilities, resources, and spaces such as common spaces, laundry, tools, gardens, childcare, and amenities, 7) a rich social agenda of regular shared meals, celebrations, festivals, workshops, and other activities.

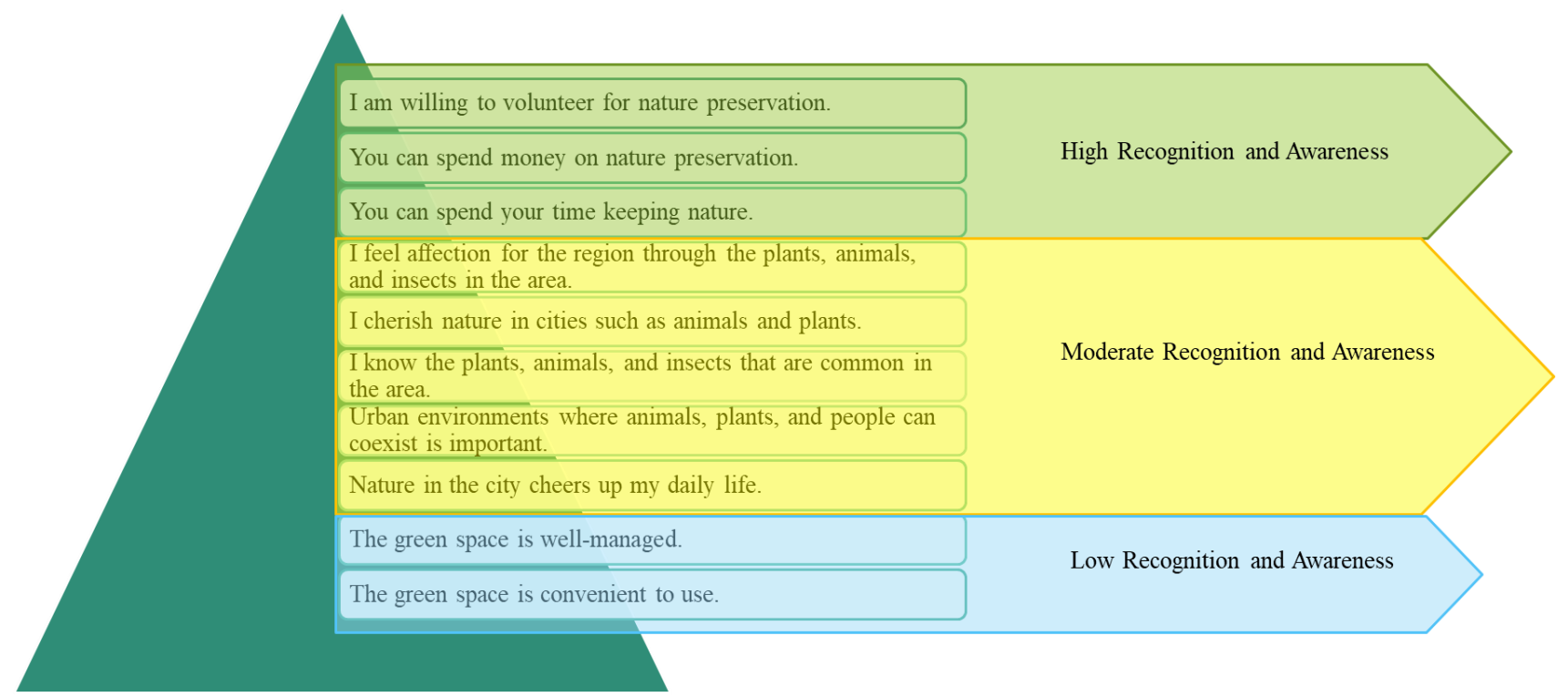

Figure 10. Factors in perceived interest in nature and green space. 
Based on these typical areas of interest in nature and green spaces, several recommendations can be proposed to develop a better quality of life, particularly in Tokiwadaira town:

1. Enhance accessibility to urban green spaces, such as replacing steps with ramps and adding signage from the housing complex to nearby green spaces. Ensure that green spaces are available within walking distance of residential areas for older adults.

2. Provide volunteering programs to manage old trees in Tokiwadaira parks and forests in order to experience nature. People with the same interests could share ideas and experiences and enhance their social bond. Community participation in nature management programs would increase residents' sense of belonging and ultimately their sense of responsibility and willingness to maintain nature and green spaces. Sinery and Manusawai (2016) also reinforced that from the perspective of conservation of natural resources, participation is a basic principle determining the success of program achievement.

3. Provide a nature exploring program for children in natural green spaces, especially in Tokiwadaira. As agents of change, informal environmental education for children highly impacts on their perceptions, preferences, and behavior towards the environment. By this means, community, children, and parents could join the seasonal program.

4. Provide opportunities for various structural activities in green spaces for elderly people to support health-promoting activities. Practitioners should be encouraged to provide a variety of structured and unstructured activities in community green spaces to support older adult participation and community engagement. As Pleson et al. (2014) described, activity instructors might be permitted to teach informal classes. Based on the level of community engagement (Bell et al. 2013), regional programs from local governments would be communicative if local bureaucracy provide information sharing and public consultation to increase community participation. Also required at the initial stages are mentoring by experts so that communities can actively engage with their own social and economic improvement, while contributing to their experience and conserving their nearby nature and green spaces (Kusnanto et al. 2016).

5. Provide a small-scale environment clean-up program, like on the home yard and meso scale, for neighborhood parks, pocket parks, greenways, etc. All citizens could participate in the clean-up, arranging/designing, and finishing phases. The cleanest and most beautiful green space could be proposed as a Tokiwadaira green space model utilizing local material, plants, and knowledge. How people organize spatial living (Wohnweisen) gives us vivid understanding of how they construct social relationships (Elias, 1983), while the output of this program in terms of the uniqueness of the social and physical environment would become an attraction in terms of the local knowledge of each dwelling (Mulyati et al, 2016).

\section{CONCLUSION}

The significant differences in perceptions of the benefits of nature and green spaces between Tokiwadaira danchi and apartment residents were related to distance from green spaces, usage for children's play, and environmental benefit by controlling dust. Interest in nature and green spaces was categorized by cherishing nature, knowing the names of creatures, feeling affection for nature, and perceiving nature and green spaces as wellmanaged and convenient places. Residents of Tokiwadaira danchi had a higher level of perception than apartment residents, except for usage for children's play. The attributes influencing perception for danchi residents were gender and age, while for apartment residents they were age, existence of children, employment status, length of stay, and existence of green spaces. There were three factors related to residents' interest in green spaces and nature: (a) high recognition and awareness, (b) moderate recognition and awareness, and (c) low recognition and awareness of nature and green spaces. The difference between danchi and apartment residents was their willingness to spend money on nature.

\section{BIBLIOGRAPHY}

Bell, K.B., Lindenfeld, L., Speers, A.E., Teisl, M.F., and Leahy, J.E., 2013. Creating Opportunity for Improving Lake-Focused Stakeholder Engagement: Knowledge-Action Systems, Pro-Environment Behavior and Sustainable Lake Management. Lakes \& Reservoirs: Research and Management, 18:514.

Elias, N., 1983. Die Hofische Gesselschaft. Suhrkamp. Frankfurt.

Fraenkel, J.R., and Wallen, N.E., 1993. How to Design and Evaluate Research in Education. McGraw-Hill Inc. Singapore.

Hidayat and Istiadah., 2011. Panduan Lengkap Menguasai SPSS 19 untuk Mengolah Data Statistik Penelitian. Media Kita. Jakarta. 
Karan, P.K., 2004. Japan in the 21st Century: Environment, Economy, and Society. The University Press of Kentucky. Kentucky.

Kim, M., Rupprecht, C.D.D., and Furuya, K., 2017. Spatial Typology in Informal Urban Green Spaces: The Case of Ichikawa City, Japan. In: Program Book of Japan Geosciences Union Meeting 2017. Chiba, 20-25 May 2017.

Kusnanto, H., Dibyosaputro, S., Hadisusanto, S., and Saraswati, S.P., 2016. Community Engagement With Urban River Improvement: The Case of Yogyakarta City. J. Manusia \& Lingkungan, 23(3):390-393.

Lucas, O.W.R., 1991. The Design of Forest Landscape. Oxford University Press. New York.

Meltzer, G., 2000. Cohousing: Verifying the Importance of Community in the Application of Environmentalism. Journal of Architecture and Planning Research, 17(2):110-132.

Mulyati, A., Soewarno, N., Ronald, A. and Sarwadi, A., 2016. Karakteristik Spasial Permukiman Vernakular Perairan di Sulawesi Tengah. J. Manusia \& Lingkungan, 23(1):122128.

Othman, A.R., dan Fadzil, F., 2014. Influence of Outdoor Space to the Elderly Wellbeing in a Typical Care Centre. Procedia - Social and Behavioral Sciences, 170:320-329.

Pleson, E., Nieuwendyk, L.M., Lee, K.K., Chaddah, A., Nykiforuk, C.I.J., and Schopflocher, D., 2014. Understanding Older Adults' Usage of Community Green Spaces in Taipei, Taiwan. International Journal of
Environmental Research and Public Health, 11:1444-1464.

Pratiwi, P.I., Furuya, K. and Sulistyantara, B., 2014․ The Difference in People's Response Toward Natural Landscape Between University Students of Japan and Indonesia. $J$. Manusia \& Lingkungan, 21(2):247-253.

Pratiwi, P.I., Sulistyantara, B., Gunawan, A., and Furuya, K., 2014 ${ }^{\mathrm{b}}$. A Comparative Study on the Perception of Forest Landscape Using List Method Between University Students of Japan and Indonesia. Jurnal Managemen Hutan Tropika, 20(3):167-178.

Ronald, R., and Alexy, A., 2011. Home and Family in Japan. Routledge, Taylor and Francis Group. London.

Roscoe, J., 1975. Fundamental Research Statistics for The Behavioral Sciences. Holt, Rinehart, \& Winston. New York.

Ross, S., and Wall, G., 1999. Evaluating Ecotourism: The Case of North Sulawesi, Indonesia. Tourism Management, 20(6):673682.

Sinery, A.S., Manusawai, J., 2016. Partisipasi Masyarakat Dalam Program Pengelolaan Hutan Lindung Wosi Rendani. J. Manusia \& Lingkungan, 23(3):394-401.

Sulistyantara, B. and Pratiwi, PI., 2011. Perencanaan Penataan Lanskap Kawasan Wisata dan Penyusunan Alternatif Program Wisata di Grama Tirta Jatiluhur, Kabupaten Purwakarta, Provinsi Jawa Barat. Jurnal Lanskap Indonesia, 3(2):58-65. 